\title{
The Effect of Granulocyte Colony Stimulating Factors (GCSF) on Expansion of CD34+ Hematopoietic Stem Cells
}

\author{
Basuki Supartono*, Bintarti Yusriana and Muttia Amalia \\ Stem Cell and Tissue Engineering Research Center, Medical Faculty of UPN Veteran Jakarta, Indonesia
}

Received: 制: December 11, 2018; Published: 制: January 04, 2019

*Corresponding author: Basuki Supartono, Stem Cell and Tissue Engineering Research Center, Medical Faculty of UPN Veteran Jakarta, Indonesia

\begin{abstract}
Stem cells are alternatives therapeutic treatment, mainly for diseases that cannot be treated by medical or surgical treatment. CD34 hematopoietic stem cells which is isolated from autologous peripheral blood cell is a good source because it's lowering immune rejection However, the limit volume of peripheral blood can be taken from a patient, limit the total number of $\mathrm{CD}_{3} 4^{+}$cell and therefore will be inadequate for therapeutic efficacy. In the previous addition of GCSF, TPO and SCF to CD34+ culture increased the number of CD34 ${ }^{+}$cell. But the addition of several cytokines will increase the cost of culture become a burden for patients who are seeking for stem cell therapy. In this study we examined the effect of GCSF on the expansion of CD34 $4^{+}$cell. For that purpose, we isolated and expanded CD34+ cell from peripheral blood using GCSF. As a control cultures, we used GCSF, TPO and SCF addition. Both culture was incubated for 10 days, and then counted the number of CD34+ cells. The results showed the amount of $\mathrm{CD} 34^{+}$cells can be increased only with GCSF. When compared to the control group, the number of CD34+ cells treated with GCSF were lower than which are an average 51,250 cells compare to 3,300,000 cells, respectively. There is a significant difference between the number of cd 34 cells treated only with GCSF and the control group $(\mathrm{p}=0.04)$. Furthermore, the differentiation potential of CD34+ $/$ GCSF expanded cells should be performed. In conclusion, GCSF alone has positive effect in increasing CD34+ cells number although the increase is lower compared to if all the treatment is combined.
\end{abstract}

Keywords: CD34+ cell; GCSF; Hematopoietic cell; Peripheral blood

Abbreviations: GCSF: Granulocyte Colony Stimulating Factors; CSF: Colony Stimulating Factors; HSC: Hematopoietic Stem Cells

\section{Introduction}

Human tissue has varying levels in regeneration capacity, even some of musculoskeletal tissues such as the cartilage and ligament have no ability to regenerate at all. In some condition when that tissues had trauma or diseased, they cannot regenerate. Until now, medical therapy has not been able to make growth or produce new tissue that tissue disorders are often end with surgical therapy such as replacement surgery. The solution is to make new tissue by regeneration therapy. Tissue engineering technique using stem cell could be the promising alternative therapy because of its ability to regenerate new tissue. Stem cells are cells that have ability to renew and multiply themselves and form cells and tissues structuring the organism body. Stem cells have some superior characteristics, namely plasticity produce regenerative tissue and prevent degeneration.
Stem cells can be categorized into embryonic stem cells and tissue stem cells. There are some limitations in using them such as ethical problem and teratoma risk. Tissues stem cells found in some tissues or organs. There are 2 types of tissue stem cells, mesenchymal stem cells and hematopoietic stem cells. Mesenchyme stem cells are potential sources of tissue engineering. However, the application of mesenchyme stem cells faces some limitations in sampling process and its nature. The sampling process causes pain and complication such as infection and sepsis. The other limitations are the characteristic of mesenchyme stem cells such as the number of cells, range of age, proliferation and its differentiation related to age of the donor. Hematopoietic stem cells are favorable because its characteristic, namely easy taking, low complication risk, and have differentiated potential without being affected by the age of the donor. 
Hematopoietic stem cells are progenitor cells forming blood cells-lymphoid cells and myeloid cells. Cells, that come from bone marrow and blood respectively. Hematopoietic stem cells have pluripotent and plasticity so that they can form nonhematopoietic cells. The change of lineage is assumed to undergo some mechanism namely trans differentiation, dedifferentiation, and cell fusion. Hematopoietic stem cells can move toward the target tissues and form new cells and tissue. Major source of HSC is CD $34^{+}$cells, the other is CD133. Today, Hematopoietic Stem Cells (HSC) are clinically efficiently used for blood cancer therapy. More research indicates other uses of HSC for non-hematopoietic tissue such as for musculoskeletal tissue especially for ischemic chronic therapy in legs and osteogenesis imperfecta. Some researchers reported the use of hematopoietic stem cells for regeneration of non-hematopoietic tissue in experimental animals. Matsumoto reported the healing of rat's femur bone fracture, through vasculogenic and osteogenic capabilities of CD34 ${ }^{+}$stem cells. Shi et al. reported the capability of $\mathrm{CD} 133^{+}$stem cells for the muscle tissue regeneration by healing of muscle injury in rats. Terayama reported the healing of osteonecrosis of rats' hip joint. Basuki reported the healing of cartilage defect of the rat's knee joint using $\mathrm{CD}^{+} 4^{+}$stem cell. It showed that $\mathrm{CD}^{+} 4^{+}$stem cell has capability of cartilage regeneration. These result indicate the differentiation potential that $\mathrm{CD}_{3} 4^{+}$cells have differentiation potential to become endothelial and osteoblasts cells.

$\mathrm{CD} 4^{+}$stem cell can be obtained by doing selection process of MNCs cells population. MNCs cells population taken by isolating the human body tissue such as solid or liquid. Skin and fat are examples from solid human body tissue whereas bone marrow, peripheral blood and cord blood are examples from liquid human body tissue. The process of isolating MNC cells from body liquids more preferable because of the easier process than isolating from solid human tissue. The collection process from bone marrow fluid and umbilical cord blood is inconveniences thus increased morbidity and easily contaminated. Therefore, collection process from peripheral blood human is safer and more comfortable for patients with some limitation [1]. The limitation of obtaining CD34 ${ }^{+}$ cells from peripheral blood is the number of cells that can be used is not enough for therapeutically purpose [2-4].

The challenge is how to increase the number of $\mathrm{CD} 34^{+}$cells from peripheral blood selection for stem cell therapy. We need effective method to increase it. The previously methods are mobilization $\mathrm{CD}_{3} 4^{+}$from the bone marrow using cell growth factors namely GCSF (Granulocyte Colony Stimulating Factors) [5,6]. Colony Stimulating Factors (CSF), is hematopoietic growth factor, which plays a role in the regulation of bone marrow cell mobilization, proliferation and differentiation [7]. In fact, this method is done by give an injection to patient that feels uncomfortable to patient, another method is expansion $\mathrm{CD} 4^{+}$cells (In vitro) in a medium containing cell growth factors. The standard method of $\mathrm{CD}_{3} 4^{+}$cells expansion is cell expansion with multiple or combination of several cell growth factors, namely GCSF, SCF, TPO. GCSF has important role in $\mathrm{CD}_{3} 4^{+}$cells expansion $[2,4,7,8]$. CD34 ${ }^{+}$cells expansion with a mixture of several growth factors is less economical. the alternative is to use only one growth factor, namely GCSF. The purpose of the study was to determine the effectiveness of administration GCSF only compared with the administration of GCSF mixed with SCF and TPO.

\section{Material \& Methods}

\section{Ethics Statement}

Research was done at Stem Cell Research and Tissue Engineering Centre, Medical Faculty of University Pembangunan Nasional Veteran, Jakarta, Indonesia. All procedures were approved by Ethical Committee of University Pembangunan Nasional Veteran, Jakarta, Indonesia. Blood donor was volunteer who has been explained all of the procedures and use of their blood samples in this study and has knowingly signed the informed consent.

\section{Blood Collection}

Human peripheral blood was collected from 2 males, 30 years, healthy donors. Donors had no history of hepatitis, HIV, malignancy, or bone marrow disease and never had chemo or radiotherapy. Donors signed informed consent and undergone a preliminary blood examination to determine infection risk of Hepatitis and HIV, and both results were negative. All procedures in taking and examination of blood samples were conducted in Al Fauzan Hospital, Jakarta, Indonesia. About $100 \mathrm{ml}$ peripheral blood was collected.

\section{Peripheral Blood CD34+ Cells Selection}

All collected blood were isolated with Ficoll gradient centrifugation and selected to $\mathrm{CD}^{+} 4^{+}$using Mini Macs column system. Blood specimens were diluted with $\mathrm{PBS}^{+} \mathrm{KCl}$ solution, filtrated with Ficoll and centrifuged. Buffy coat layers were taken, washed and supernatant was removed until only MNC cells were available to be counted and viability checked. Afterward we used MACS isolation CD34+ kit (Militenyi) for CD34+ selection. MNC cells were washed and labeled by adding $300 \mu$ l buffer solution (auto MACS TM Rinsing Solution and MACS BSA Stock Solution, 20:1), FcR Blocking $100 \mu \mathrm{l}$, and CD34+ micro-beads $100 \mu \mathrm{l}$, and the suspension was incubated for 30 minutes at $2-8^{\circ} \mathrm{C}$. Subsequently, $10 \mathrm{~mL}$ buffer solution was added to cell suspensions and centrifuged. The supernatant was removed, and cells were re-suspended with 500 L buffer. Cells were separated with separator column. About $500 \mathrm{~L}$ of buffer was added into the column along with the cell suspension. The column was washed with $500 \mathrm{~L}$ buffer solution three times. $\mathrm{CD} 34^{+}$cells retained in the column were pushed with a syringe into a tube. Cell suspensions were centrifuged, the supernatant was removed, and cells were counted amount of cell and its viability.

\section{CD34+ Cells Expansion}

We prepared 24 well plates, 12 well plates for experimental group and 12 well plates for control group. We prepared two type of cell culture medium. Medium 1 : 104 CD34+ cells, GCSF $100 \mathrm{ng} / \mathrm{ml}$, Miltenyi), Stem line II Hematopoietic Stem Cell Expansion medium (Sigma). Medium 2: 104 CD34+ cells, in GCSF (100ng/ml, Miltenyi), TPO (100ng/ml, Miltenyi), SCF medium (100ng/ml, Miltenyi), Stem line II Hematopoietic Stem Cell Expansion medium (Sigma). We 
put medium in well plate: medium 1 for experimental group and medium 2 for control group 1 (exin 12 well plate. We observed it for 10 days, and $\mathrm{CD} 34^{+}$cell was counted in day $10^{\text {th }}$.

About $10.000 \mathrm{CD}^{4} 4^{+}$cells were planted in each well from 24 well plates using the stem line medium containing GCSF cytokines. As a control the Stem line medium was added to the GCSF, SCF and TPO cytokines. The dose of GCSF used was $100 \mathrm{ng} / \mathrm{ml}$ for each group and repeated 4 times $[3,9]$. For control it is used a medium that added with GCSF(100 ng/ml), SCF (100 ng/ml) and TPO $(100 \mathrm{ng} / \mathrm{ml})$. Same as with the addition of GCSF, then the control had 4 times repetition too. The cultures were observed for 10 days and then counted for the amount of cells.

\section{Statistical Analysis}

Data were descriptively and comparatively analyzed by SPSS version 17.0 and expressed as mean and SD. The comparative analysis from amount of $\mathrm{CD} 34^{+}$cells were evaluated using t test. P, 0.05 was considered statistically significant [10].

\section{Result \& Discussion}

\section{Peripheral Blood CD 34 Cell Selection}

The result of donor blood examination was $13.9 \mathrm{Hb}$ level of g/ $\mathrm{dl}$, leucocyte count of $7.4 \times 10^{3} / \mathrm{mm}$, and platelet count of $209 \times 10^{3}$ / L. The amount of CD34+ cells : $3.7 \times 10^{6}$ cells, with $95 \%$ viability.

\section{CD34+ Cells Expansion}

In the experimental groups (GCSF medium) and the control groups(GCSF,SCF,TPO medium), the expansion of $\mathrm{CD} 4^{+}$cells were occurred well without any contamination. According to observation until the $10^{\text {th }}$ days, the cell form was maintained (like previous form) and didn't attach to the plastic. The number of cells continued to increase but on the $10^{\text {th }}$ day the increase of $\mathrm{CD} 34^{+}$cells is more common in the control group. On the $10^{\text {th }}$ day, in the experimental groups amount of CD34+ cells are $5.125 \times 10^{4}$ while at the control groups amount of CD34+ cells are $330 \times 104$ (Table 1) and (Figure $1)$. There was significant difference ( $t$ test, $p=0.04$ ) in amount of $\mathrm{CD} 4^{+}$cell produced from cultures using GCSF alone with cultures using a combination of GCSF, TPO, and SCF.

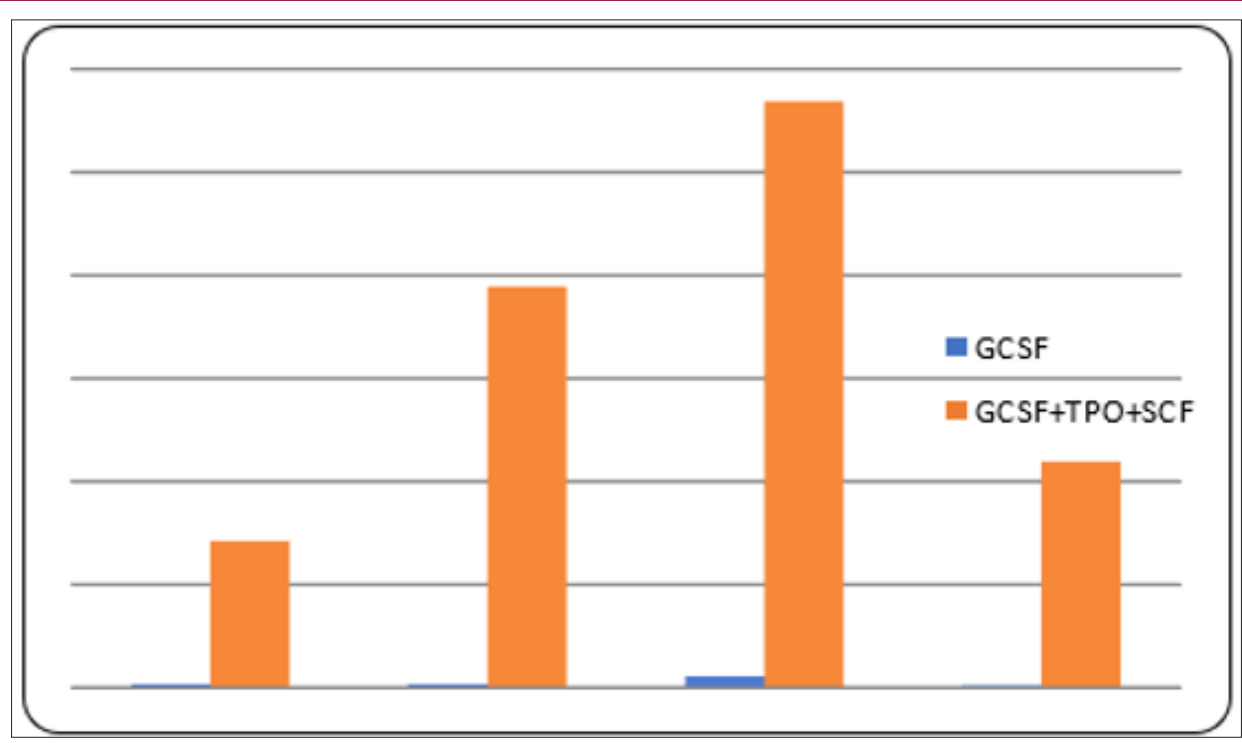

Figure 1: Comparison between amount of $\mathrm{CD} 34^{+}$cells in experimental group and control group on the $1^{\text {st }}$ day and $10^{\text {th }}$ day, in every repetition.

Table 1: Comparison between amount of CD34+ cells in experimental group and control group on the $1^{\text {st }}$ day and $10^{\text {th }}$ day.

\begin{tabular}{|c|c|c|}
\hline Group & Day $\mathbf{1}$ & Day 10 \\
\hline Experimental Group (GCSF medium) & $1 \times 10^{4}$ cells & $5.125 \times 10^{4} \mathrm{cells}$ \\
\hline Control Group (GCSF, SCF, TPO medium) & $1 \times 10^{4}$ cells & $330,0 \times 10^{4} \mathrm{cells}$ \\
\hline
\end{tabular}

This result showed that the cell proliferation with GCSF alone give lower cells proliferation compare to cells treated with combination of GCSF, TPO, and SCF. This result was in accordance with the statement that TPO and SCF cytokines can increase the number of peripheral blood progenitor cells and work in synergy with the GCSF $[2,11,12]$.

Figure 2 showed that the amount of $\mathrm{CD} 34^{+}$cells continued to increase both in control and experimental group from the $1^{\text {st }}$ day until the $10^{\text {th }}$ day. However, this result hasn't shown how the differentiation of $\mathrm{CD} 34^{+}$cell yet. For this reason, the study is still continuing with characterization phase. It is hoped that the characterization results will show whether the CD34+ ${ }^{+}$cells are still hematopoietic cells, or it can differentiate to mesenchymal cells too. There are some limitations in this study such as time and amount of the cells. The time for the expansion of stem cells in this study is only 10 days, which is not enough to expand more stem cells. We suggest for the next study, the time for expanding the stem cell should be prolonged and the amount of cells should be increased. We need further research for solve this questions. 


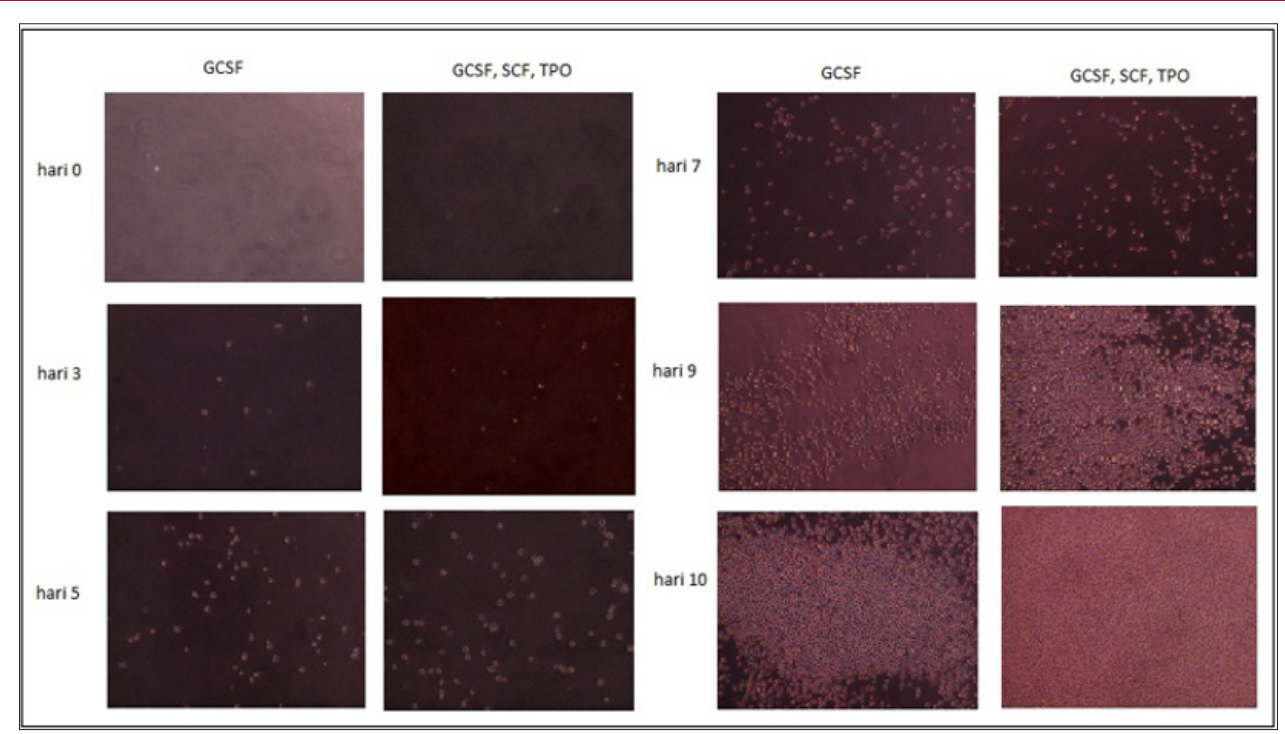

Figure 2: Growth of $\mathrm{CD}^{+} 4^{+}$cell in culture with GCSF alone and control $(\mathrm{GCSF}+\mathrm{TPO}+\mathrm{SCF})$ from $1^{\text {st }}$ day $u n t i l 10^{\text {th }}$ day.

\section{Conclusion}

GCSF has positive effect on $\mathrm{CD}_{3} 4^{+}$cells expansion in vitro but the effect is less than the combination of GCSF, SCF and TPO.

\section{Acknowledgment}

We thank for Prita Kusumaningsih MD, Obstetric and Gynaecologic Specialist, Muzayyana Sakiinah MD, Ns Latifah, Khurnia Savitri, Sofia Wardhani MD. MKK, and all of the Staff of Al Fauzan Hospital for invaluable help in this research.

\section{References}

1. Supartono B (2013) Hyaline cartilage regeneration on osteochondral defect by intraarticuler injection of human peripheral blood CD34 ${ }^{+}$Cells, hyaluronic acid and growth factor in a rat model. Disertation. Faculty of Medicine University of Indonesia.

2. Berens C, Heine A, Muller J, Held SAE, Mayer K, et al. (2016) Variable resistance to freezing and thowing of CD34-positive stem cell and lymphocyte subpopulations in leukapheresis product. Cytotherapy 18(10): 1325-1331.

3. Dubrovsky L, Wong ECC, Perez Albuerne E, Loechelt B, Kamani N, et al. (2011) CD34 ${ }^{+}$Collection efficiency as a function of blood volumes processed in pediatric autologous peripheral blood stem cell collection. Journal of Clinical Apheresis 26: 31-137.

4. Menendez P, Redondo O, Rodriguez A, Lopez Berges MC, Ercilla G et al. Comparison between a lyse-and-then-wash mehod and a luse-non-wash technique for the enumeration of $\mathrm{CD}_{3} 4^{+}$hemopoetic progenitor cells. Cytometry. 34(6): 264-271.
5. Jaiswal SR, Zaman S, Chakrabarti A, Sen S, Mukherjee S, et al. (2016) Improved outcome of refractory/relapsed acute myeloid leukemia following post-transplantation cyclophosphomide based haploidentical transplantation with myeloablative conditioning and early prophylactic GCSF-mobilized donor lymphocyte infusions. Biology of Blood and Marrow Transplantation 22(10): 1867-1873.

6. Leveque El Mouttie L, Vu T, Lineburg KE, Kuns RD, et al. (2015) Autophagy is required for stem cell mobilozation by G-CSF. Blood 125(19): 29332936.

7. Drake AC, Khoury M, Leskov I, Iliopoulu BP, Fragoso M, et al. (2011) Human CD34+ $\mathrm{CD} 133^{+}$hematopoetic stem cells cultured with growth factors including angptl5 efficiently engraft adult NOD-SCID Il2ry ${ }^{-1}$ (NSG) Mice. Plos ONE 6(4): e18382.

8. Wagemaker G, Hartong SC, Neelis KJ, Egeland, T, Wognum AW (1998) In vivo expansion of homopoetic stem cells. Stem Cells 16 (Suppl 1): 185191.

9. Pigano M, Gauvreau K (2012) Principles of Biostatistics, Duxbury Press, 34. California, USA.

10. Boiron JM, Dazey B, Cailliot C, Launay B, Attal M, et al. (2006) Largescale expansion and transplantation of CD34(+) hematopoietic cells: In vitro and In vivo confirmation of neutropenia abrogation related to the expansion process without impairment of the long-termengraftment capacity. Transfusion 46(11): 1934-1942.

11. Duarte RF, Frank DA (2011) The Synergy between Stem Cell Factor (SCF) and Granulocytecolony-Stimulating Factor (GCSF): Molecular basis and clinical relevance. Leukemia and Lymphoma 43(6): 1179-1187.

12. Kaushansky K (1997) Thrombopoetin: Understanding and manipulating platlet production. Annu Rev Med 48: 1-11. 
ISSN: 2574-1241

DOI: 10.26717/BJSTR.2019.12.002304

Basuki Supartono. Biomed J Sci \& Tech Res

(c) (P) This work is licensed under Creative

Submission Link: https://biomedres.us/submit-manuscript.php

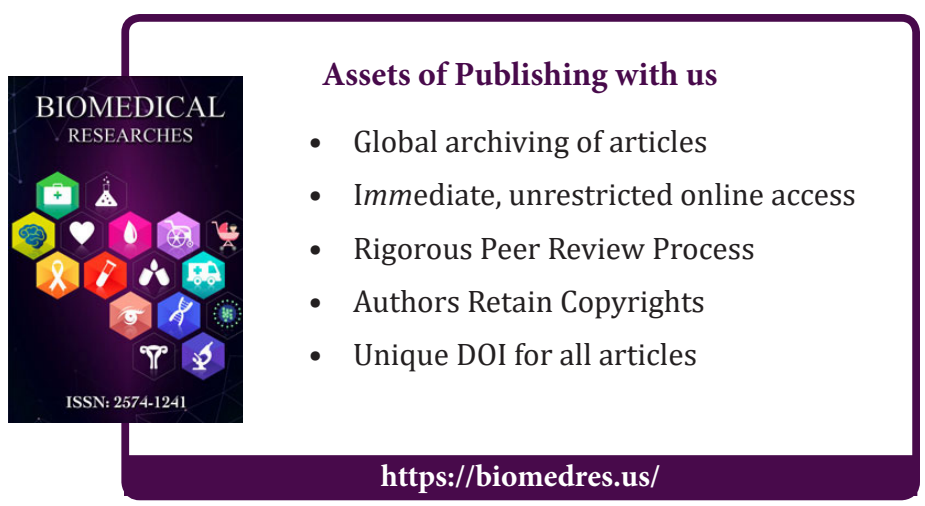

